\title{
O01 - Validation of asthma and eczema in population-based Swedish health registers
}

\author{
Anne K Örtqvist*, Cecilia Lundholm, Björn Wettermark, Jonas F Ludvigsson, Weimin Ye, Catarina Almqvist \\ From 3rd Pediatric Allergy and Asthma Meeting (PAAM) \\ Athens, Greece. 17-19 October 2013
}

\section{Background}

Valid measures of asthma and eczema in epidemiological studies may be a challenge. Population-based registers can be useful as they do not rely on recall and allow for follow-up. Our aim was to ascertain if asthma/eczema medication is a suitable proxy for asthma/eczema and to validate register-based asthma diagnoses.

\section{Method}

Data were retrieved on all 0-17-year-old individuals with reported asthma/eczema medication in the Swedish Prescribed Drug Register (SPDR) and/or an asthma diagnosis in the National Patient Register (NPR) between 2005-2009 ( $\mathrm{N}=121,944)$. Medical records retrieved from prescribing units, for 2,250 randomly selected individuals, were reviewed to estimate the proportion of individuals with 1) asthma/eczema medication in the SPDR who had a doctor diagnosis of asthma/ eczema and/or; 2) fulfilled predefined criteria of asthma by the Swedish Paediatric Society (positive predictive value, PPV); 3) an asthma diagnosis in the NPR verified as asthmatics by predefined criteria.

\section{Results}

PPV for asthma medication as a proxy for a doctor diagnosis of asthma was 0.68 (95\%CI: 0.64-0.72) in pre-school children (0-4.5 years) and 0.89 (95\%CI: 0.85-0.92) in school-age children ( $>4.5-17$ years). The corresponding PPV for predefined criteria of asthma was 0.75 (95\%CI: 0.70-0.78) and 0.94 (95\%CI: 0.91- 0.96) in pre-school children and school-age children respectively. Almost all (99\%) of school-age children and $78 \%$ of pre-school children with an asthma diagnosis in the NPR were verified as asthmatics. PPV for eczema medication as a proxy for an eczema diagnosis was estimated to 0.45 (95\% CI: 0.38 0.51 ) in children 0-17 years.

\footnotetext{
Karolinska Institutet, Stockholm, Sweden
}

(c) 2014 Örtqvist et al; licensee BioMed Central Ltd. This is an Open Access article distributed under the terms of the Creative Commons Attribution License (http://creativecommons.org/licenses/by/2.0), which permits unrestricted use, distribution, and reproduction in any medium, provided the original work is properly cited. The Creative Commons Public Domain Dedication waiver (http:// creativecommons.org/publicdomain/zero/1.0/) applies to the data made available in this article, unless otherwise stated.

\section{Conclusion}

Asthma medication is the SPDR is a suitable proxy for asthma in older children; the same approach is insufficient for eczema. Furthermore, the quality of asthma diagnoses in the NPR is high. This validation study of two Swedish registers opens for future large nation-wide studies on asthma.

Published: 28 February 2014

doi:10.1186/2045-7022-4-S1-01

Cite this article as: Örtqvist et al: 001 - Validation of asthma and eczema in population-based Swedish health registers. Clinical and Translational Allergy 2014 4(Suppl 1):01.
Submit your next manuscript to BioMed Central and take full advantage of:

- Convenient online submission

- Thorough peer review

- No space constraints or color figure charges

- Immediate publication on acceptance

- Inclusion in PubMed, CAS, Scopus and Google Scholar

- Research which is freely available for redistribution 